\title{
Tinjauan Ilmu Falak terkait Fenomena Gerhana Bulan Penumbara terhadap Kebijakan Salat Gerhana pada Ormas Islam
}

\author{
Rizka Amalia*, Titin Suprihatin \\ Bandung, Indonesia. \\ *rzkam123@gmail.com, titinsuprihatin62@gmail.com
}

Prodi Hukum Keluarga Islam, Fakultas Syariah, Universitas Islam

\begin{abstract}
A lunar eclipse is a sign of the greatness of Allah SWT, where every Muslim is shunned if an eclipse occurs to pray to Allah, perform eclipse prayers, takbir, and give alms. In the source of Islamic law, lunar eclipses are not fully discussed whether umbra or penumbra eclipses occur. In 2016 it was the appeal of the Tarjih and Tajdid Muhammadiyah Council in Yogyakarta that explained that no eclipse prayers were allowed because the simple penumbra was done. The purpose of this research is to study the concept of astronomical fiqh of penumbra eclipse phenomena and to understand the views of Muhammadiyah, Islamic Union and Nahdlatul Ulama on penumbra eclipse phenomena related to eclipse prayer policies. This study uses qualitative methods by describing and analyzing concepts. The conclusion from this research is the first, namely the penumbra lunar eclipse in figh terms is incomplete. However, in the world of astronomy, umbra and penumbra shadows can be understood with the help of optical devices. Secondly, the second choice of Islam does not prescribe the eclipse prayer compilation of the penumbra eclipse of the Moon on the grounds that eclipse Changes all three does not prescribe eclipse prayer.
\end{abstract}

Keywords: Penumbra Eclipse, Islamic Organizations, Prayer.

Abstrak. Gerhana bulan merupakan salah satu tanda kebesaran Allah SWT. Di mana setiap umat Islam disunnahkan jika terjadi gerhana untuk berdoa kepada Allah, melaksanakan shalat gerhana, bertakbir, dan bersedekah. Dalam sumber hukum Islam, gerhana Bulan tidak dijelaskan dengan rinci apakah yang terjadi adalah gerhana bulan umbra ataupun penumbra. Pada tahun 2016 terdapat himbauan Majelis Tarjih dan Tajdid Muhammadiyah di Yogyakarta yang menjelaskan bahwa tidak disunnahkan untuk melakukan shalat gerhana karena yang terjadi adalah gerhana Bulan penumbra. Tujuan penelitian ini adalah untuk mengetahui konsep fikih astronomi fenomena gerhana Bulan penumbra dan untuk mengetahui pandangan Muhammadiyah, Persatuan Islam dan Nahdlatul Ulama terhadap fenomena gerhana Bulan penumbra terkait dengan kebijakan salat gerhana. Penelitian ini menggunakan metode kualitatif dengan upaya mendeskripsikan dan menganalisis konsep. Simpulan dari penelitian ini pertama, bahwa gerhana bulan penumbra dalam istilah fikih tidak dijelaskan secara rinci. Akan tetapi, dalam dunia astronomi, bayangan umbra dan penumbra dapat diketahui dengan bantuan alat optik. Kedua, pandangan ketiga ormas Islam sama-sama tidak mensyariatkan salat gerhana ketika gerhana Bulan penumbra dengan alasan bahwa gerhana bulan penumbra jika dilihat dari kasat mata tidak terlihat seperti terjadi gerhana dan jika dilihat dengan alat yang canggih cahaya Bulan hanya terlihat redup saja. Sehingga ketiganya tidak mensyariatkan salat gerhana.

Kata Kunci: Gerhana Bulan Penumbra, Ormas Islam, Salat. 


\section{A. Pendahuluan}

Gerhana dalam bahasa Arab berasal dari kata kusuf. Gerhana dikenal dengan sebutan kusuf dan khusuf. Pada dasarnya istilah kusuf dan khusuf digunakan untuk menyebut gerhana Matahari maupun gerhana Bulan. Dalam bahasa Inggris dikenal dengan istilah eclipse. Gerhana Bulan adalah peristiwa saat sebagian atau keseluruhan wajah Bulan yang dalam fase purnama tertutup oleh bayangan Bumi. Sehingga Bulan menjadi tampak gelap; ada kalanya sebagian pada saat gerhana sebagian ataupun seluruhnya pada saat gerhana Bulan total. Dalam Al-Quran tidak ada penjelasan mengenai gerhana, tetapi dalam hadis terdapat penjelasannya seperti hadis tentang gerhana yang diriwayatkan oleh Imam Bukhari yakni: "Telah menceritakan kepada kami Amr ibn Aun berkata: Telah menceritakan kepada kami Kholid, dari Yunus, dari al-Hasan, dari Abu Bakrah berkata: Kami berada dekat Rasulullah SAW. Ketika pada suatu hari terjadi gerhana matahari. Rasulullah SAW berdiri seraya menghela cedarnya sampai masuk masjid. Kami pun masuk pula ke dalam masjid. Beliau shalat dengan kami dua raka'at sampai matahari terang kembali. Nabi SAW bersabda: "Terjadinya gerhana matahari dan bulan, bukanlah karena seseorang meninggal dunia. Maka apabila kamu melihat keduanya, shalatlah dan mendo'alah hingga segalanya terang kembali."

Dilihat dari hadis tersebut tidak menjelaskan adanya gerhana umbra dan gerhana penumbra. Hadis tersebut hanya menjelaskan tentang gerhana Matahari dan Bulan saja. Namun, dalam astronomi ada istilah gerhana umbra dan gerhana penumbra. Dalam penerapan ibadah salat gerhana ini, ada beberapa pendapat tentang salat atau tidaknya saat terjadi gerhana penumbra. Ada yang mengatakan bahwa salat gerhana ini adalah sunnah muakadah (sunnah yang ditekankan). Ada pula yang mengatakan bahwa salat gerhana ketika gerhana penumbra tidak disunahkan seperti, pada tanggal 23 Maret 2016 saat terjadinya gerhana Bulan penumbra menurut Majelis Tarjih dan Tajdid Muhammadiyah di Yogyakarta tidak disunatkan untuk melakukan salat gerhana Bulan.

Berdasarkan latar belakang yang telah diuraikan, maka tujuan penelitian akan diuraikan sebagai berikut:

1. Untuk mengetahui konsep gerhana bulan penumbra perspektif fikih astronomi.

2. Untuk mengetahui pandangan ormas Islam terhadap salat gerhana pada saat gerhana bulan penumbra.

3. Untuk mengetahui analisis fikih astronomi terhadap pandangan ormas Islam tentang salat gerhana Bulan penumbra.

\section{B. Metodologi Penelitian}

Penelitian ini menggunakan metode kualitatif dengan upaya mendeskripsikan dan menganalisis konsep. Simpulan dari penelitian ini pertama, bahwa gerhana Bulan penumbra dalam istilah fikih tidak dijelaskan secara rinci. Akan tetapi, dalam dunia astronomi, bay angan umbra dan penumbra dapat diketahui dengan bantuan alat optik. Kedua, Pandangan ketiga ormas Islam sama-sama tidak mensyariatkan salat gerhana ketika gerhana Bulan penumbra dengan alasan bahwa gerhana Bulan penumbra jika dilihat dari kasat mata tidak terlihat seperti terjadi gerhana dan jika dilihat dengan alat yang canggih cahaya Bulan hanya terlihat redup saja. Sehingga ketiganya tidak mensyariatkan salat gerhana.

Gerhana Bulan atau Khusuful qamar (Eclipse of The Moon/LunarEclipse) adalah apabila terjadi sebagian atau seluruh piringan Bulan memasuki kerucut bayangan inti bumi (umbra). Ketika terjadinya gerhana Bulan, Bulan menjadi gelap ketika memasuki bayangan Bumi tetapi masih ada beberapa sinar matahari yang dibiaskan di sekitar Bumi oleh atmosfer. Biasanya awan, debu, dan polusi mempengaruhi warna dan kecerahan pada saat gerhana Bulan terjadi dan membuatnya menjadi merah pudar. Gerhana Bulan dibedakan menjadi tiga macam, yakni gerhana Bulan total, gerhana Bulan sebagian, dan gerhana Bulan penumbra.

Dalam Al-Quran memang tidak membahas secara rinci tentang gerhana, namun ada beberapa ayat yang menyinggung mengenai benda langit seperti ayat berikut ini:

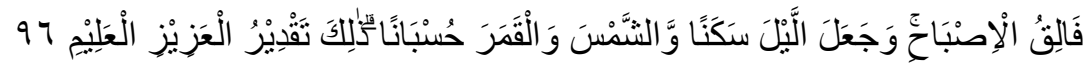


96. Dia menyingsingkan pagi dan menjadikan malam untuk beristirahat, dan (menjadikan) matahari dan bulan untuk perhitungan. Itulah ketetapan Allah Yang Maha Perkasa, Maha Mengetahui. (Q.S Al-An'am 6: 96)

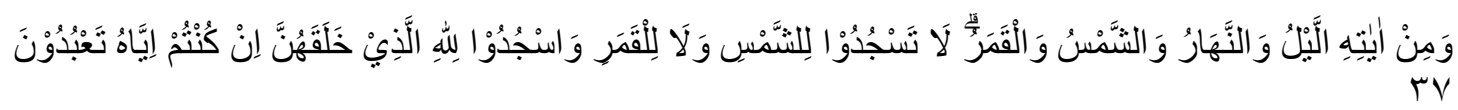

37. Dan sebagian dari tanda-tanda kebesaran-Nya lah malam, siang, matahari, dan bulan. Janganlah bersujud kepada matahari dan jangan pula kepada bulan, tetapi bersujudlah kepada Allah yang menciptakannya, jika kamu hanya menyembah kepada-Nya. (Q.S Fushsillat 41: 37)

Adapun hadis yang menjelaskan mengenai gerhana, yakni sebagai berikut.

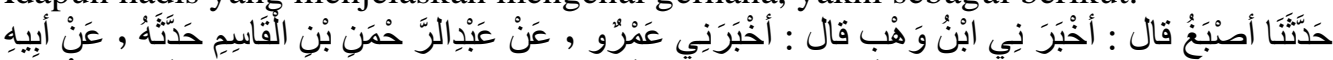

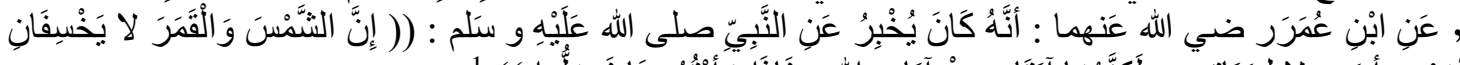

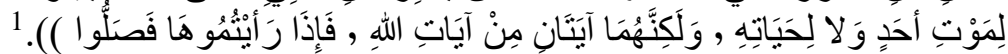

Telah mengabarkan kepada kami Ashbagu berkata: Telah memberitahu Ibn Wahb berkata: Telah memberitahuAmr, dari Abdrahman Ibn Al-kasim mengabarkan, dari Abi, dari Ibn Umar r.a: mengabarkan dari Nabi SAW, bahwa terjadinya gerhana matahari dan bulan bukanlah karena mati atau lahirnya seseorang. Tetapi keduanya adalah dua tanda di antara sekian banyak tanda-tanda kebesaran Allah. Maka apabila kamu melihat gerhana, shalatlah!"

Hadis di atas memerintahkan apabila terjadi gerhana maka laksanakanlah salat gerhana. Hal ini disyariatkan dan merupakan hal yang disepakati, namun terjadi perselisihan mengenai hukum dan tata caranya. Mayoritas ulama mengatakan bahwa hukumnya adalah sunnah mu'akkadah (yang sangat dianjurkan). Hal ini berbeda dengan pendapat Abu Awanah dalam kitab shahihnya dan Ibnu Al-Manayyar yang menukil dari Abu Hanifah menyatakan bahwa hukumnya adalah wajib.

Prinsip dasar terjadinya gerhana Bulan yaitu ketika Matahari, Bumi dan Bulan berada pasa satu garis yaitu saat Bulan beroposisi atau saat Bulan pernama; sehingga pada saat tersebut akan melewati bayangan Bumi seperti gambar berikut ini:

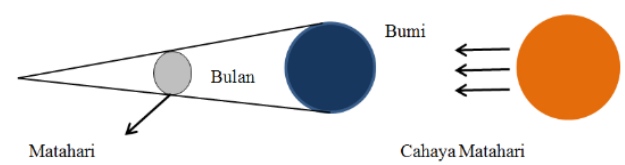

Gambar 2.1 Posisi Astronomis Saat Gerhana Bulan

(Sumber: Ahmad Izzuddin, Ilmu Falak Praktis)

Bayangan yang dibentuk oleh Bumi mempunyai dua bagian yaitu. Pertama bagian yang paling luar yang disebut bayangan penumbra atau bayangan semu (bayangan ini tidak perlu gelap) dan bagian dalam yang disebut dengan bayangan umbra atau bayangan inti. Dengan begitu, bentuk lingkaran Matahari lebih besar dari pada lingkaran Bumi sehingga bayangan umbra Bumi membentuk kerucut sedangkan bentuk dari bayangan penumbra Bumi berbentuk kerucut terpancung dengan puncaknya di Bumi yang semakin jauh bayangan ini semakin membesar sampai menghilang di ruang angkasa.

Perhatikan pada gambar berikut ini: 
Pada bayangan penumbra hanya sebagian piringan Matahari yang ditutupi oleh Bumi, sedangkan pada bayangan umbra seluruh piringan Matahari tertutup oleh Bumi, sehingga ketika Bulan melewati umbra, Bulan akan terlihat gelap karena cahaya Matahari yang masuk ke Bulan dihalangi oleh Bumi. Fenomena ini dikenal dengan gerhana Bulan total.

\section{Hasil Penelitian dan Pembahasan}

Dalam istilah fikih, gerhana Bulan penumbra tidak dijelaskan dalam Alquran maupun hadis. Didalam hadis sendiri hanya menyebutkan gerhana matahari dan gerhana bulan saja. Istilah gerhana matahari dan gerhana Bulan disebutkan dengan kata "kusuf" dan "khusuf". Untuk gerhana matahari disebutkan istilah kusuf dan untuk gerhana Bulan disebutkan istilah khusuf. Istilah tersebut sebagaimana pendapat dari ahli fuqaha seperti pendapat Tsa'lab dan Al Jauhari. Hal ini berbeda dengan pendapat Al Qadhi Iyadh yang menukil dari sebagian ulama. Mereka berpendapat sebaliknya, bahwa matahari disebutkan khusuf dan Bulan disebutkan kusuf. Pendapat ini keliru, sebab di dalam Alquran Surah Al Qiyamah ayat 8 menyebutkan kata خَسَفْ yang artinya adalah Bulan.

Namun, gerhana Bulan penumbra termasuk ke dalam istilah Astronomi yakni ada pada macam-macam gerhana Bulan. Gerhana Bulan penumbra adalah fenomena alam yang terjadi ketika piringan Bulan hanya melewati bayang-bayang penumbra bumi maka disebut dengan istilah gerhana penumbra. Sedangkan untuk gerhana Bulan total atau gerhana Bulan cincin terjadi pada gerhana umbra. Gerhana umbra adalah piringan bulan yang melewati bayangan inti bumi atau bayangan umbra. Perbedaan antara gerhana penumbra dan gerhana umbra sangatlah jelas dilihat dari peranan dalam dan luar. Untuk bagian luar itu adalah penumbra dan untuk bagian dalam adalah umbra. Ketika terjadi gerhana Bulan penumbra, cahaya Bulan hanya tampak redup saja. Namun, ketika yang terjadi gerhana umbra maka cahaya bulan tampak gelap total. Fenomena ini yang disebut dengan gerhana Bulan total.

Adapun pandangan ormas Islam mengenai fenomena gerhana Bulan penumbra terkait dengan kebijakan salatnya. Pertama, menurut Muhammadiyah gerhana Bulan penumbra ini jika dilihat dengan alat yang canggih hanya akan tampak piringan yang utuh, tidak tampak terpotong dan tidak hilang, serta cahaya Bulan yang sedikit redup. Sehingga masyarakat yang melihatnya dengan kasat mata tidak bisa membedakan apakah Bulan tersebut sedang mengalami gerhana. Sedangkan gerhana Bulan penumbra ini tidak bisa dibedakan juga antara sedang terjadi gerhana atau hanya sedang Bulan purnama saja. Dengan demikian, gerhana Bulan penumbra ini tidak disunnahkan untuk melaksanakan salat gerhana karena tidak termasuk dalam kategori sedang terjadi gerhana. Kedua, menurut Persatuan Islam gerhana Bulan penumbra ini ketika zaman Rasulullah SAW tidak ada yang melaksanakan salat khusuf atau salat gerhana. Kemudian, gerhana Bulan penumbra ini tidak mudah untuk diamati dengan kasat mata, sehingga pengamatannya harus menggunakan alat yang canggih dan didukung oleh beberapa ahli falakiyah dalam mengamati benda langit. Dalam pengamatannya gerhana Bulan penumbra ini hanya intensitas cahaya saja yang sedikit redup. Sehingga, menurut Persatuan Islam gerhana Bulan penumbra ini tidak disunnahkan untuk melaksanakan salat gerhana. Ketiga, menurut Nahdlatul Ulama gerhana Bulan penumbra dalam istilah astronomi atau falakiyah ini adalah jenis gerhana yang dimana benda langit Bulan hanya tampak meredup dan pinggiran lingkaran puringnya tidak sedikitpun berkurang. Secara literatur fikiyah tidak terdapat pendapat sunnahnya salat khusuf (bulan). Nahdlatul Ulama mensyaratkan salat gerhana menjadi beberapa bagian yakni, apabila terjadi gerhana matahari atau gerhana Bulan disuatu wilayah tertentu, indikatornya adalah matahari atau bulan tersebut tampak berkurangnya lingkaran matahari atau bulan yang sewajarnya tampak penuh. Dengan demikian, apabila hanya meredup saja cahayanya tidak riwayat hadits yang menganjurkan salat karena kejadian tersebut.

\section{Kesimpulan}

Berdasarkan pembahasan dalam penelitian ini, peneliti menyimpulkan beberapa hasil penelitian sebagai berikut:

1. Dalam istilah fikih gerhana Bulan penumbra tidak dijelaskan secara jelas atau secara 
utuh baik dalam Alquran maupun hadis. Di dalam hadis terkait gerhana hanya menjelaskan tentang gerhana secara umum saja, tidak ada istilah umbra atau penumbra. Sedangkan dalam istilah astronomi gerhana Bulan itu terbagi menjadi dua yakni gerhana penumbra dan gerhana umbra. Gerhana penumbra adalah piringan Bulan atau matahari hanya melewati bayangan penumbra bumi. Sedangkan gerhana umbra adalah piringan Bulan atau matahari yang melewati bayangan umbra bumi. Keduanya samasama mengalami gerhana. Disyariatkannya salat gerhana apabila terlihat oleh kasat mata. Namun, gerhana Bulan penumbra ini sulit dilihat oleh kasat mata, maka tidak disyariatkannya salat gerhana.

2. Pandangan Muhammadiyah, Persatuan Islam dan Nahdlatul Ulama terkait dengan fenomena gerhana Bulan penumbra terkait dengan kebijakan salat gerhana yakni samasama tidak mensyariatkan untuk melaksanakan salat gerhana. Alasan tidak disyariatkan salat gerhana karena beberapa hal, diantaranya tidak bisa dilihat dengan kasat mata sehingga mengharuskan untuk dilihat dengan alat yang canggih, cahaya Bulan hanya terlihat redup saja, tidak ada riwayat hadits terkait dengan gerhana penumbra, dan gerhana Bulan penumbra tidak termasuk gerhana dalam istilah fikiyah.

3. Ketiga ormas Islam sudah sesuai dengan fikih karena berbagai alasan yang mendukung seperti tidak adanya riwayat hadits yang mensyariatkan salat gerhana ketika penumbra. Begitupun dengan astronominya, ketiga ormas Islam ini sama-sama berpendapat bahwa gerhana Bulan penumbra memang termasuk gerhana. Namun, untuk istilah fikiyahnya tidak disunnahkan untuk salat gerhana.

\section{Daftar Pustaka}

[1] Ahmad Ainul Yaqin, F. F. (2018). Hadis Gerhana dan Wafatnya Ibrahim Ibn Muhammad. Tahkim, 54-67.

[2] Al-Bukhari, I. A. (1998). Shahih al-Bukhari. Saudi Arabia: Bait Al-Ifkar.

[3] Al-Qur'an, Y. P. (2008). Al-Qur'an dan Terjemahnya. Bandung: Sinar Baru Algensindo.

[4] Askar, S. ((tt.)). Kamus Arab - Indonesia Al-Azhar. (t.tp): (t.p).

[5] Indonesia, K. A. (2013). Ilmu Falak Praktik. Jakarta: Sub Direktorat Pembinaan Syariah Dan Hisab Rukyat.

[6] Izzuddin, A. (2012). Ilmu Falak Praktis. Semarang: PT Pustaka Rizki Putra.

[7] Jayusman, M. (2011). Fenomena Gerhana Dalam Wacana Hukum Islam dan Astronomi. Al'Adalah, 237-250.

[8] Moche, D. L. (2009). Astronomy: a self teaching guide. New Jersey: John Wiley \& Sons.

[9] Sabda, A. (2019). Ilmu Falak Rumusan Syar'i dan Astronomi. Bandung: Persis Pers.

[10] Stevenson, A. (2010). Oxford Dictionary of English. New York: Oxford University Press. 